\title{
Right to buy ... time to move? investigating the moving behaviour of right to buy owners in the UK
}

\author{
Maarten van Ham • Lee Williamson • Peteke Feijten • Paul Boyle
}

Received: 10 July 2011/Accepted: 24 May 2012/Published online: 13 June 2012

(C) The Author(s) 2012. This article is published with open access at Springerlink.com

\begin{abstract}
Part of the political argument in favour of the right to buy (RTB) was that it would stimulate the economy by encouraging the inter-regional mobility of those in public sector housing. This is the first study to examine whether RTB-owners are indeed more mobile than those in social housing. Using longitudinal data from the British household panel survey and panel regression models we show that the probability of a RTB-owner making a long distance move falls between that of social renters and owner occupiers. However, the difference between RTB-owners and homeowners or social renters is not significant. Social renters are significantly less likely to move over long distances than traditional owners. The results also suggest that RTB-owners are less likely than traditional owners to move for job related reasons, but more likely than social renters.
\end{abstract}

Keywords Right to buy - Residential mobility · Migration · Moving reasons · Longitudinal data $\cdot$ United Kingdom

\section{Introduction}

The right to buy (RTB) legislation was introduced in the 1980 housing act ${ }^{1}$ by Thatcher's conservative government elected in 1979. The legal RTB is one of the most significant

\footnotetext{
${ }^{1}$ In fact there was different legislation in different countries: the Housing Act 1980 in England and Wales, the Housing Tenants Rights Etc. Act 1980 in Scotland (Jones and Murie 2006) and the Housing (Northern Ireland) Order 1983 which introduced the RTB scheme for Housing Executive tenants.
}

\section{M. van Ham $(\bowtie)$}

OTB Research Institute for the Built Environment, Delft University of Technology,

PO Box 5030, 2600 GA Delft, The Netherlands

e-mail: m.vanham@tudelft.nl

L. Williamson · P. Boyle

Longitudinal Studies Centre-Scotland, School of Geography and Geosciences, University

of St Andrews, Irvine Building, North Street, St Andrews KY16 9AL, Scotland, UK

P. Feijten

The Netherlands Institute for Social Research, PO Box 16164, 2500 BD The Hague, The Netherlands 
transformations of the British social housing market. Since it was introduced, over 2.7 million public sector dwellings have been sold to sitting tenants at prices well below market value, transferring wealth from the state to private households (Jones and Murie 2006). The primary reason for these sales was to stimulate homeownership and to respond to the desire of some tenants to own their properties. Although it was never part of the original discussion on the RTB, the political argument was used by some that the policy would stimulate the economy by encouraging the inter-regional mobility of those in the public sector (Boyle 1997). Tony Durant, member of parliament for the conservatives said in 1980 "The exercise of this right will also bring about greater mobility. One of the fundamental troubles of our economy in this country is that people find it very difficult to move" (Hansard 1980). As part of the same discussion, the Earl of Mansfield said "If people wish to move, because they get a better, or different, job in another part of the country, what better chance have they of availing themselves of such opportunities if they own their own homes and can sell them. This is an important part of the thinking" (Hansard 1980).

According to the discussions in Parliament, social housing was seen as a major barrier to spatial mobility "there is overwhelming evidence that owner-occupiers are more mobile than are public tenants. Public tenants often have to stay where they are by virtue of the local authority's allocation policies. So in a situation in which we want to encourage the maximum mobility of labour [...] that maximum mobility depends to an extent on ownership of homes" (The earl of mansfield in Hansard 1980). Various studies in Europe and the US show that homeowners are less mobile than renters (e.g. Rossi 1955; Boyle 1993; Boheim and Taylor 2002; Helderman et al. 2004, 2006), but these studies often conflate private and public renting. Hughes and McCormick (1981, 1985, 1987) found for the UK that living in public housing, rather than home-ownership, is the major tenure-related barrier to inter-regional mobility. Those resident in public housing were more likely to move residence over short distances than those in owner-occupied housing, but much less likely to migrate over long distances and these results were confirmed in a number of later studies (Coleman and Salt 1992; Boyle 1995, 1997). This lack of long distance mobility among social renters likely reflects a range of factors. First, social renters may be more likely to work in jobs that are only advertised locally, rather than nationally (Saunders 1985). Second, they have fewer resources to allow a move into private renting or owner occupied housing elsewhere. Third, the administrative controls imposed upon the distribution of public housing make it difficult for tenants to move between local authorities. Public housing policies were designed to house those most in need of public housing, but they prioritised the needs of those from within their own jurisdictions above the needs of those from other local authority areas. These policies therefore enabled high levels of short distance migration between council houses within their areas, as people's circumstances altered, but tended to restrict (long distance) migration between areas (Boyle 1995).

Thatcher's government was particularly concerned about the lack of job related migration among those in public housing. Neoclassical labour market theory identifies migration as an important instrument for individual career advancement (see Blau and Duncan 1967; van Ham 2002; Mulder and van Ham 2005), and this should have the effect of diminishing regional differences in wages and unemployment (Sjaastad 1962). Any barriers to people's ability to migrate can therefore harm both the economy and individual careers, making this issue a major policy concern (Boheim and Taylor 2002; van Ham 2002). Thus, Thatcher linked the inability to move to national economic performance: "Frequently investment goes where there are skilled people wanting work. But there must 
be some mobility. If today people aren't willing to move as their fathers did, the economy can't thrive" (Thatcher 1980).

It was imagined that freeing up the housing market by removing the debilitating effect of public housing policies would help to reduce constraints on mobility (Black and Stafford 1988). However, discussions in parliament reflected that not everyone was convinced this would work. In 1980 Lord Monson said "... will giving the right to buy encourage labour mobility? Perhaps, but not, I think, to the extent imagined" (Hansard 1980). Lord Drumalbyn added "No one can say whether it will increase mobility, but it could at least set the scene to make it easier for people to move" (Hansard 1980). And Jack Straw added "few households that buy as sitting tenants would be likely to otherwise move away; nearly all would have remained local authority tenants for the rest of their lives" (Hansard 1980). Despite the discussions in parliament on the potential effect of the RTB on mobility, there has been no research investigating whether social renters became more mobile after buying their house. There have been a number of studies investigating the resales of former council dwellings (Forrest et al. 1995, 1996; Williams and Twine 1994; Chaney and Sherwood 2000; Pawson and Watkins 1998a, b), but these studies focused on the characteristics of the buyers of these dwellings, while we are interested in the sellers (those who bought the dwelling from the social landlord under the RTB).

This is the first study to examine whether the RTB legislation did indeed 'free-up' those in public housing who bought their homes. We compare the mobility behaviour of RTBowners with social renters, private renters and 'traditional' homeowners. Unfortunately, due to data constraints (mainly small numbers, see data and methods section), it is not possible to investigate moves for job reasons separately. Instead we look at moves over short and long distance separately.

\section{Literature review}

The large volume of houses sold under the RTB since 1980 has dramatically altered the UK housing market (Jones and Murie 2006). The RTB initially gave only those living in council housing the right to buy their dwelling and was later extended to tenants of other non-charitable social landlords, such as housing associations. Over the years, changes in policies and regional variations in the policies have incrementally introduced a high level of complexity into the RTB legislation (see Jones and Murie 2006 for an excellent overview). One of the most recent changes is that in november 2010 members of the Scottish parliament have voted to end the RTB for new council and social housing tenants because of housing shortages in the social sector.

Over the past 25 years, there have been large fluctuations and regional differences in the number of sales, with peaks in 1982 and 1989. The RTB caused the distribution of dwellings by tenure to change radically: in $198157.6 \%$ of all dwellings were owneroccupied and by 2003 this had risen to $72.3 \%$. As a result of the RTB and changes in the provision of social housing in the UK, the share of local authority rented dwellings decreased from 29.2 to $13.0 \%$ and the share of housing association dwellings increased from 2.2 to $7.4 \%$.

The consequences of the RTB legislation have been studied intensively in the late 1980s and the early 1990s. There are roughly two strands of literature on the RTB. The first focusses on those who bought their dwelling under the RTB and the second focusses on resales of former public sector homes. The literature on the selective nature of sales under the RTB has shown that the RTB has tended to involve better-off tenants, the more 
desirable properties, in the more desirable areas. More specifically, during the early years of the RTB, the majority of tenant purchasers were middle- to old-aged married couples with non-dependent children (Forrest and Murie 1988). They also tended to be from higher social classes with white collar, skilled or semi-skilled occupations (Williams et al. 1987), with at least one and often two earners in the household (Kerr 1988; Lynn 1991; Forrest and Murie 1984a, b; Jones and Murie 2006). Almost half of the buyers had been tenants for 20 years or more and previous moves within the council sector had allowed them to secure relatively desirable dwellings. Few of these initial RTB purchasers stated that they wished to move on in the near future and many expected to stay in their house for the rest of their lives (Forrest and Murie 1984a, b; Foulis 1985). A survey by James et al. (1991) suggested that the RTB option was used by many tenants to secure their future in an area, rather than as a means of escape from 'welfare' housing or, indeed, as a means of enabling future mobility. It is now well recognized that a combination of factors has created an increased residualisation and stigmatization of the remaining council sector, has led to a shortage of social housing for relets in some regions, and has left a concentration of social housing in poor quality unpopular estates (Burrows 1999; Forrest and Murie 1988, 1990; Pawson and Bramley 2000; Jones and Murie 1998).

A second strand of literature investigates the resales of former public sector dwellings (see Forrest et al. 1995, 1996; Williams and Twine 1994; Chaney and Sherwood 2000; Pawson and Watkins 1998a, b). Although this strand of literature is related to the topic of the present study, it approaches the subject from a different angle. We are interested in the behaviour and characteristics of those who bought their house under the RTB and subsequently moved on. The resales literature takes as a starting point the former public sector dwelling and investigates who subsequently buys these dwellings from the original RTB purchaser, and what the impact of these resales is on local communities, especially rural areas. Some of the resales literature also (briefly) investigates the impact of the RTB on the vendors' subsequent housing career (for example Pawson and Watkins 1998a), but do not compare these careers with the careers of traditional home owners and renters. The resales literature does give some insight into the mobility of RTB owners. In a study using a nationally representative survey of households in over 3,000 dwellings which had been resold after the initial sitting-tenant purchased it under the RTB, Forrest et al. (1996) report that based on their own estimations, by the end of 1991 about $14 \%$ of the properties sold under the RTB in England had been resold.

Those suggesting that tenants who bought their dwelling under the RTB might be among the least mobile council tenants cast doubts over the supposition that the sale of council housing to existing tenants would increase working class mobility (Boyle 1995; Diets and Haurin 2003). Thus, it was entirely possible that the barriers to mobility caused by mechanisms to allocate social housing might simply be replaced by the barriers to mobility which arise from homeownership (see Forrest 1987; Oswald 1999; Nickell 1998; Van Ommeren et al. 2000 on homeownership). Mobility of homeowners is strongly dependent on booms and busts in the housing market (Forrest and Murie 1992) and regional house price differentials. Hamnett (1992) suggested that high prices in the South east were likely to be a more important factor overall in restricting labour mobility than council policies. Besides these general barriers to mobility, those who bought their house under the RTB might in addition find it difficult to find a buyer for their property because of the quality of the dwellings, or because the neighbourhood they are located in.

Perhaps surprisingly, then, there has been no detailed research on the mobility behaviour of those who bought their house under the RTB. If the RTB indeed stimulated interregional mobility, we would expect those who bought their house as sitting tenants to be 
more mobile over long distances than those who remained in social housing. On the other hand, selective sorting into the RTB programme of tenants with the strongest desire to stay put, might cause those who bought their house to be the least mobile. In any case, we should expect low mobility in the first years after sitting tenants bought their house because anti-speculation penalties applied if households moved in the first 3-5 years. We should also expect a drop in short distance mobility of those who bought under the RTB, compared to council tenants, because they now face the same barriers to mobility as traditional homeowners. We might also find regional and temporal differences in the effect of the RTB on migration as regional differences in the supply and cost of housing are known to have an effect on interregional migration, and because the supply and costs of housing change over time (Dieleman 2001).

\section{Data and methods}

To test whether there are differences in the mobility behaviour of RTB owners and those in other tenures, longitudinal data was needed. The suitability of several nationally representative longitudinal studies containing information on both the RTB and mobility were assessed for this study, and three data sources were considered. The first is the ONS longitudinal study of England and Wales (ONS-LS), which includes a $1 \%$ nationallyrepresentative sample of the England and Wales population. The ONS-LS follows people between 1971 and 2002, covering the entire RTB period, and has a very large sample size (over 900,000 study members in total). Using census data it is in theory possible to identify whether people bought their home under the RTB (by identifying tenure changes without physical moves), but a major disadvantage of the data is that information on tenure is only available at 10 year intervals. As a result it is only possible to identify immobile RTB owners (those who can be observed in two census years) and because of this limitation we concluded that the usefulness of the ONS-LS data for our study was too limited.

The second dataset we explored was the national child development study (NCDS). The sample consists of all children born in 1 week in march 1958 in Great Britain. The 2000 wave sample size was just over 16,000 (including around 1,000 immigrants born in the sample week who were added in waves 1-3). Only waves from 1978 (respondents were aged 20) and onwards are relevant because we can assume that respondents did not start their independent housing careers before this year. In both 1981 (at age 23) and 1991 (at age 33) respondents were asked whether they bought their house as sitting tenants. After 1991 there is no information on buying as a sitting tenant. Although the NCDS data is much richer than the ONS-LS data, the usefulness of the data for our purposes is limited because also here we observe a selection of stayers.

The third dataset we explored was the British household panel survey (BHPS) which is a nationally representative sample of 5,500 households (10,300 interviewed individuals) drawn in 1991 from 250 areas in Great Britain. Additional booster samples of 1,500 households for Scotland and Wales and 2,000 households for Northern Ireland were added to the main sample in 1999 and 2001 respectively, resulting in a total sample size of around 10,000 households. In the BHPS the same individuals are re-interviewed each successive year on many topics. For each wave, information was available on actual moving behaviour, reasons for moving, the region in which people live, and individual and household characteristics. A potential problem when studying migration with panel data is that those who move are more likely to leave the panel compared to those who stay. Buck (2000) has shown that although this problem is present in the BHPS, its effect on the study 
of migration is limited because migrant attrition is relatively small. After careful assessment, the BHPS was the best available dataset for our purposes. The main shortcoming of the BHPS was that the number of RTB owners identified, and therefore the number of moves by RTB owners, is relatively low, which has consequences for the robustness of the models (see discussion in the results section and the conclusion). However, the BHPS data is the best possible data source to study the mobility behaviour of RTB owners over a longer period of time.

Residential mobility decisions are made by households rather than individuals (Coulter et al. 2012), and therefore we have created an household-year file based on the BHPS. Households including one person were given the characteristics of the individual making up the household. For couple households the situation was more complicated. Because the household reference person in the BHPS is not constant over time (even if household composition does not change), and is biased towards males, a random person was selected from couples for the first year that they were in the BHPS, resulting in 101,206 household year records. We identified RTB-owners in two different ways. For the first wave (Wave 1991) we used the question "At the time you bought this house/flat were you already living here as a tenant?" If yes and the vendor was a social landlord, such as a local authority or a housing association, we assumed that respondents had bought their house/flat under the RTB. For subsequent waves (Wave B to O 1992 onwards) we identified RTB-owners by observing tenure change for non-movers. If tenure changed from social renter to homeowner without a move respondents were identified as sitting tenants who became RTBowners. This exercise resulted in a total of 4,430 RTB-owner years, or $4.45 \%$ of all household years.

The main dependent variable indicates whether a household has not moved, moved over short distance, or moved over long distance between two interview years. We defined long distance moves as moves over $35 \mathrm{~km}$. We also tried alternative specifications such as 40 and $50 \mathrm{~km}$, with little change to our modelling results. $35 \mathrm{~km}$ can be regarded as long distance because for most people this moves them out of their daily activity space (van Ham 2002). We had a concern that moves caused by union dissolution would bias the outcomes of our models if the rate of union dissolution varied between tenures. This appeared to be the case in our data: RTB-owners were much less likely to split up than traditional owners or social renters. When separation/divorce occurred the household was removed from the sample so that moves resulting from separations were not counted. In the BHPS moves were recorded in $6.6 \%$ of the household-years (this is lower than average population mobility due to the removal of moves associated with separation/divorce).

As expected, of all household years in the data, private renters move most often (moves in $23.9 \%$ of household years), followed by 'other' renters $(16.8 \%)$, and social renters (7.2\%). Traditional owners (5.1\% of household-years) and RTB-owners (3.6\%) moved the least. Only $14.6 \%$ of moves in the BHPS are over long distances. Social renters moved the least over long distance ( $6.4 \%$ of moves), followed by private renters (11.8\%), RTBowners $(11.9 \%)$, traditional owners $(18.7 \%)$ and 'other' renters $(25.6 \%)$. We identified only 137 moves by RTB-owners in the BHPS data. Arguably this is a very low absolute number, which has consequences for the robustness of our analyses, and which will be reflected in the standard errors of the RTB parameters. Although we are probably pushing the boundaries of the BHPS data, we feel that the analyses are still worthwhile as this is the best possible dataset available to study the mobility behaviour of RTB owners over a longer period of time. 
We used panel logistic regression to model the probability of moving. We estimated two sets of models. In the first set the dependent variable indicated whether the household moved over short distance (1) versus did not move (0). In the second set of models the dependent variable indicated whether the household moved over long distance (1) versus did not move (0). The independent variables in our mobility models were lagged by 1 year (i.e., we took the characteristics of the household in the year prior to the move because conceptually, pre-move characteristics should be better predictors of moving than postmove characteristics). The independent variables used were: age of oldest partner in the household; tenure; economic activity in five categories (single employed, single nonemployed, couple both employed, couple non-employed, couple employed/non-employed); highest educational qualification in household; log of household income (corrected for inflation using ONS inflators); self-reported health based on daily activities among those in the household; room stress based on the number of rooms and the size of the household; age of the youngest child in the household. We also added three regional housing market characteristics (using Samples of Anonymised Records Areas, which roughly resemble Local Authorities) to the BHPS dataset: median and mean house prices; percentage social renting; and working age unemployment rates. See Table 1 for summary statistics of the main variables.

There are a range of selection issues which might bias the outcomes of our models. We set out to use formal statistics to control for selection bias, but the number of RTB-owners in our data was very low, and there were too many selection mechanisms potentially relevant simultaneously (selection into social housing, into the RTB, out of the RTB), which were impossible to disentangle. We therefore focused on the most important selection issue, which is structural to the BHPS data: differences between respondents who were already RTB-owners at the start of the panel (1991) and those who became RTBowners during the panel.

As indicated above, we used two ways to indentify RTB-owners in the BHPS. The problem with those identified in 1991 as RTB-owners (referred to as 'pre 1991 RTB-owners' in the rest of this paper) is that they are a selective sample of stayers: households who bought their house under the RTB and can still be observed in that dwelling in 1991. All those RTBpurchasers who had since moved on to another dwelling before 1991 could no longer be identified as (former) RTB-owners (most are likely to have moved on to other owneroccupied dwellings and will be counted among the traditional owners). Thus, 'stayers' are over represented among 'pre 1991 RTB-owners' compared to those who became RTBowners during the panel (whom we could follow up, whether they moved or stayed). Including this relatively immobile group may have caused an underestimation of the mobility of RTB-owners. However, because we are dealing with a relatively low number of RTB-owners in our sample, we were keen to retain them in the analysis and we therefore ran all our models for four different research populations: (1) all cases (66,622 household years); (2) all cases except pre-1989 RTB-owners (these are more likely to be a selection of stayers than 1989-1991 RTB-owners who bought more recently before the panel started) $(64,393$ household years); (3) all cases except 'pre 1991 RTB-owners' (for those who became RTBowners during the panel purchase year is known) (63,574 household years); (4) only households in social renting in 1991 some of whom became RTB-owners during the panel (purchase year is known) (15,178 household years). These different samples allow us to provide a more comprehensive assessment of the likely effects of the RTB on migration. It is not possible to say which one of the four research populations is the 'correct' one as each has advantages and disadvantages. Populations 3 and 4 offer probably the most robust modelling opportunities. In the models using research populations 1 and 2 we also included a dummy 
Table 1 Variable summary statistics (unit of analysis: household years)

\begin{tabular}{|c|c|c|c|}
\hline & $\begin{array}{l}\text { Frequency } \\
(\%)\end{array}$ & $\begin{array}{l}\text { Mean } \\
(\mathrm{SD})\end{array}$ & $\begin{array}{l}\text { Minimum/ } \\
\text { maximum }\end{array}$ \\
\hline No move & 94.9 & & \\
\hline Short distance moves $(<35 \mathrm{~km})$ & 4.4 & & \\
\hline Long distance moves $(\geq 35 \mathrm{~km})$ & 0.7 & & \\
\hline Pre 1991 RTB dummy & 3.6 & & \\
\hline \multicolumn{4}{|l|}{ Tenure } \\
\hline Traditional owner & 66.8 & & \\
\hline Social renter & 22.0 & & \\
\hline RTB-owner & 5.1 & & \\
\hline Private renter & 5.1 & & \\
\hline Renter 'other' & 0.9 & & \\
\hline Age (in years) & & $54.40(16.33)$ & 16-99 \\
\hline $\mathrm{HH}$ income (log of income in pounds) & & $4.30(0.36)$ & $-0.20-5.91$ \\
\hline \multicolumn{4}{|l|}{ Household } \\
\hline Single-employed & 11.8 & & \\
\hline Single-non-employed & 24.3 & & \\
\hline Couple_-both employed & 32.2 & & \\
\hline Couple_-both non-employed & 15.9 & & \\
\hline Couple-mixed & 15.7 & & \\
\hline \multicolumn{4}{|l|}{ Education } \\
\hline No and low qualification & 50.3 & & \\
\hline Med qualification (A levels) & 36.3 & & \\
\hline High qualification (degree) & 13.4 & & \\
\hline \multicolumn{4}{|l|}{ Children } \\
\hline No children & 70.3 & & \\
\hline Youngest aged $0-4$ & 9.5 & & \\
\hline Youngest aged $5+$ & 20.2 & & \\
\hline Room stress (rooms/person) cut at 8 & & $2.22(1.22)$ & $0.20-8$ \\
\hline \multicolumn{4}{|l|}{ Health } \\
\hline No limitations & 72.9 & & \\
\hline Health limits daily activities & 27.1 & & \\
\hline \multicolumn{4}{|l|}{ Ethnicity } \\
\hline All HH members white ethnic & 96.8 & & \\
\hline $\mathrm{HH}$ member of non-white origin & 3.2 & & \\
\hline \multicolumn{4}{|l|}{ Regional characteristics for local Authorities } \\
\hline$\%$ Social renting & & $22.30(8.90)$ & $5.12-69.17$ \\
\hline \% Unemployed (working age) & & $7.29(3.09)$ & $1.00-28.01$ \\
\hline Mean house prices & & $83 \mathrm{k}(40,457.09)$ & $33 \mathrm{k}-411 \mathrm{k}$ \\
\hline
\end{tabular}

Source Author's calculations using BHPS data for both short and long distance moves combined $(n=67,123)$, with the exception of the last 3 variables which were based on $n=66,876$

variable identifying 'pre-1991 RTB-owners'. We used this dummy variable to assess whether the 'pre-1991 RTB-owners' behaved in a different way than those who became RTB-owners during the panel study period. 


\section{Results}

To gain more insight into possible selection bias originating from selective entry into the RTB we first modelled the probability of becoming a RTB-owner. We found that higher income social renters were the most likely to become a RTB-owner (results not shown). Economic activity status also contributed to the probability of becoming a RTB-owner: dual earner couples were the most likely to become RTB-owners, followed by couples with one earner and employed singles, then followed by non-employed couples and nonemployed singles. Those with a medium to higher level of education were more likely than those with a low level of education to become RTB-owners. Finally, poor health has a significant negative effect on the probability to become a RTB-owner. The results show that financially stable and healthy social renters were the most likely to buy their house under the Right to Buy. These findings are consistent with the existing literature (see for an overview Jones and Murie 2006). Because the selection mechanism into the RTB is likely not to be independent from the selection mechanism into long distance migration (income, economic activity, education and health all influence long distance migration as well) this might lead us to overestimate the effect of the RTB on long distance mobility.

Table 2 presents the results from a series of panel logistic regression models of the probability to move over short distance (reference category are non-movers). As discussed above, we used four different research populations to gain insight into the extent to which the 'pre 1991 RTB-owners' are a selected group of stayers. We also included a dummy variable identifying 'pre 1991 RTB-owners' in Models 1 and 2, but this variable was not significant. We also ran Models 1 and 2 without the 'pre 1991 RTB dummy' and although the parameter estimates of the main RTB dummy variable changed somewhat, the overall conclusions and significance levels stayed the same.

The main variable of interest in Table 2 is tenure, with traditional owners as the reference category. In Models 1-3, social renters, private renters and other renters were significantly more likely to move over short distances than traditional owners. RTB-owners did not differ significantly from traditional owners. Further testing showed that RTBowners were significantly different from social renters $(p<0.01)$, providing some indication that once social renters become RTB-owners they behave more like traditional owners, at least with regard to short distance mobility. In Model 4, we compared RTBowners and social renters; once again RTB-owners were significantly less likely to move over short distances than social renters. It is noteworthy that the tenure parameters are almost identical between Models 1 and 3, indicating that the different definitions of the research populations did not have an effect on the modelling outcomes. This suggests that selection bias is not affecting our estimation of short distance mobility.

Table 2 also contains a set of control variables and all the results are in line with what we expected based on the residential mobility literature (see for an overview van Ham 2012). The probability of moving decreased with increasing age of the oldest household member (Models 1-4). With increasing household income the probability of moving decreased (Models 1-3). However, for social renters the probability of moving increased with income (Model 4), presumably because higher incomes provide social renters with more opportunities to improve their situation. Singles were more likely to move over short distances than couples, and couples consisting of two non-employed people were the least likely to move (Models 1-3). The probability of moving over short distances increased with level of education in all four models while the presence of children over the age of 5 had a negative effect on short distance moves (Models 1-4). Room stress-defined as the number of rooms per person-had a negative effect on mobility. The more rooms per 
Table 2 Probability of short distance move (reference no move) using panel logistic regression for 4 different research populations

\begin{tabular}{|c|c|c|c|}
\hline Model 1 & Model 2 & Model 3 & Model 4 \\
\hline Everyone & $\begin{array}{l}\text { Everyone less } \\
\text { pre-1989 } \\
\text { RTB-owners }\end{array}$ & $\begin{array}{l}\text { Everyone less } \\
\text { pre } 1991 \\
\text { RTB-owners }\end{array}$ & $\begin{array}{l}\text { Social renters } \\
\text { and RTB- } \\
\text { owners }\end{array}$ \\
\hline$n=66,622$ & $\mathrm{n}=64,393$ & $\mathrm{n}=63,574$ & $\mathrm{n}=15,178$ \\
\hline $\mathrm{HHs}=10,260$ & $\mathrm{HHs}=10,028$ & $\mathrm{HHs}=9,937$ & $\mathrm{HHs}=2,963$ \\
\hline Coef. & Sig. & Coef. & Coef. \\
\hline
\end{tabular}

Fixed part

Pre 1991 RTB dummy

0.276

Tenure

Traditional owner (Ref, Models 1-3)

Social renter (Ref Model 4)

RTB-owner

Private renter

Renter 'other'

Age

Age square

Household income

Household

Single-employed (ref)

Single-non-employed

Couple-both employed

Couple-both non-employed

Couple-mixed

Education

No and low (ref)

Med qualification (A levels)

High qualification (degree)

Children

No children (ref)

Youngest aged 0-4

Youngest aged 5+

Room stress

Health

No limitations (ref)

Health limits daily activities

Ethnicity

All white ethnic (ref)

One or more non-white $\mathrm{HH}$ members

Constant

Random part

Variance

0.35

$\begin{array}{rrrrrrrr}0.406 & * * * & 0.402 & * * * & 0.400 & * * * & & \\ -0.174 & & -0.171 & & -0.171 & & -0.515 & * * * \\ 1.557 & * * * & 1.556 & * * * & 1.556 & * * * & & \\ 1.157 & * * * & 1.172 & * * * & 1.174 & * * * & & \\ -0.114 & * * * & -0.115 & * * * & -0.116 & * * * & -0.094 & * * * \\ 0.001 & * * * & 0.001 & * * * & 0.001 & * * * & 0.001 & * * * \\ 0.053 & & 0.076 & & 0.076 & & -0.372 & * * *\end{array}$

$\begin{array}{rrrrrrr}0.032 & & 0.066 & & 0.069 & & 0.251 \\ -0.222 & * * * & -0.203 & * * * & -0.200 & * * * & 0.038 \\ -0.345 & * * * & -0.345 & * * * & -0.358 & * * * & 0.066 \\ -0.275 & * * * & -0.259 & * * * & -0.250 & * * * & -0.204\end{array}$

$0.161 \quad * * * \quad 0.161 \quad * * * \quad 0.161 \quad * * * \quad 0.265$

$0.299 \quad * * * \quad 0.297 \quad * * * \quad 0.296 \quad * * * \quad 0.271$

$\begin{array}{rrrrrrrr}0.008 & & 0.003 & & 0.006 & & 0.000 & \\ -0.353 & * * * & -0.357 & * * * & -0.353 & * * * & -0.265 & * * \\ -0.132 & * * * & -0.138 & * * * & -0.140 & * * * & -0.219 & * * *\end{array}$
0.196
0.192
0.196
0.095

$\begin{array}{llll}-0.167 & -0.152 & -0.148 & -0.356\end{array}$

$\begin{array}{llll}0.234 & 0.161 & 0.183 & 1.750\end{array} * * *$

0.35

0.36

0.31 
Table 2 continued

\begin{tabular}{|c|c|c|c|c|c|c|c|c|}
\hline & \multicolumn{2}{|c|}{ Model 1} & \multicolumn{2}{|c|}{ Model 2} & \multicolumn{2}{|c|}{ Model 3} & \multicolumn{2}{|c|}{ Model 4} \\
\hline & \multicolumn{2}{|c|}{ Everyone } & \multicolumn{2}{|c|}{$\begin{array}{l}\text { Everyone less } \\
\text { pre-1989 } \\
\text { RTB-owners }\end{array}$} & \multicolumn{2}{|c|}{$\begin{array}{l}\text { Everyone less } \\
\text { pre } 1991 \\
\text { RTB-owners }\end{array}$} & \multicolumn{2}{|c|}{$\begin{array}{l}\text { Social renters } \\
\text { and RTB- } \\
\text { owners }\end{array}$} \\
\hline & \multicolumn{2}{|c|}{$\mathrm{n}=66,622$} & \multicolumn{2}{|c|}{$\mathrm{n}=64,393$} & \multicolumn{2}{|c|}{$\mathrm{n}=63,574$} & \multicolumn{2}{|c|}{$\mathrm{n}=15,178$} \\
\hline & \multicolumn{2}{|c|}{$\mathrm{HHs}=10,260$} & \multicolumn{2}{|c|}{$\mathrm{HHs}=10,028$} & \multicolumn{2}{|c|}{$\mathrm{HHs}=9,937$} & \multicolumn{2}{|c|}{$\mathrm{HHs}=2,963$} \\
\hline & Coef. & Sig. & Coef. & Sig. & Coef. & Sig. & Coef. & Sig. \\
\hline Intraclass correlation & \multicolumn{2}{|l|}{$9.6 \%$} & \multicolumn{2}{|l|}{$9.6 \%$} & \multicolumn{2}{|c|}{$9.8 \%$} & \multicolumn{2}{|c|}{$8.6 \%$} \\
\hline Log likelihood & \multicolumn{2}{|l|}{-10890.1} & 623.1 & -1 & 497.3 & & \multicolumn{2}{|c|}{-2751.73} \\
\hline
\end{tabular}

Source Author's calculations using data from the BHPS

$* p<0.10 ; * * p<0.05 ; * * * p<0.01$

person, the less likely the household was to move. Having health problems had a positive effect on the probability of moving over short distance. Most of these moves will be associated with finding a dwelling that better fits the health situation of the household. Finally, households with one or more members from non-white ethnic minority groups were less likely to move than all white households, consistent with findings elsewhere (van Ham and Feijten 2008; van Ham and Clark 2009).

Table 3 presents a set of four panel logistic regression models of the probability to move over long distance (reference category are non-movers). Again, results are presented for the four different research populations. Also in Table 3 the dummy variable identifying 'pre 1991 RTB-owners' was not significant. The tenure variable shows that social renters were significantly less likely to move over long distances than traditional owners. The signs for the RTB-owner parameters were negative, but insignificant (Models 5-7). The findings indicate that also over long distance, RTB-owners behaved more similar to traditional owners than to social renters, although a more detailed test showed that the parameters of RTB-owners and social renters were not significantly different. This indicates that over long distances, the moving behaviour of RTB-owners was in between the behaviours of traditional owners and social renters. In Model 8, only including social renters and during-panelRTB-owners, RTB-owners were also not found to be different from social renters in their long distance moving behaviour. The effects of the control variables in the models of long distance were similar in direction to those in the models of short distance mobility. The main differences were that non-employed singles were the least likely to move over long distance, and households with children under the age of 5 were less likely to move than other households (with and without children). In the long distance models, the effects of ethnicity and health were not significant.

We also ran models (results not shown) which took into account the fact that RTBowners-who bought their dwellings with considerable discounts (up to $70 \%$ )-faced a penalty if they moved within 3-5 years (penalty periods differed over time and geographically) after buying their house as sitting tenants. We excluded all moves within the first few years after becoming a RTB-owner or after the last move (for other tenures) to make RTB-owners and others tenures more comparable. These models showed similar outcomes to those presented in Tables 2 and 3.

We also looked at the regional and temporal differences in short and long distance mobility rates (results not shown). We followed two routes to investigate potential regional 
Table 3 Probability of long distance move (reference no move) using panel logistic regression for 4 different research populations

\begin{tabular}{|c|c|c|c|}
\hline Model 5 & Model 6 & Model 7 & Model 8 \\
\hline Everyone & $\begin{array}{l}\text { Everyone less } \\
\text { pre-1989 } \\
\text { RTB-owners }\end{array}$ & $\begin{array}{l}\text { Everyone less } \\
\text { pre } 1991 \\
\text { RTB-owners }\end{array}$ & $\begin{array}{l}\text { Social renters } \\
\text { and RTB- } \\
\text { owners }\end{array}$ \\
\hline $\mathrm{n}=64,199$ & $\mathrm{n}=62,023$ & $\mathrm{n}=61,229$ & $\mathrm{n}=14,512$ \\
\hline $\mathrm{HHs}=10,221$ & $\mathrm{HHs}=9,990$ & $\mathrm{HHs}=9,899$ & $\mathrm{HHs}=2,896$ \\
\hline Coef. & Coef. & Coef. & Coef. \\
\hline
\end{tabular}

\section{Fixed part}

Pre 1991 RTB dummy

Tenure

Traditional owner (Ref, Models 1-3)

Social renter (Ref Model 4)

RTB-owner

Private renter

Renter 'other'

Age

Age square

Household income

Household

Single-employed (ref)

Single-non-employed

Couple-both employed

Couple-both non-employed

Couple-mixed

Education

No and low (ref)

Med qualification (A levels)

High qualification (degree)

Children

No children (ref)

Youngest aged 0-4

Youngest aged 5+

Room stress

Health

No limitations (ref)

Health limits daily activities

Ethnicity

All white ethnic (ref)

$\mathrm{HH}$ member of non-white origin

Constant $\begin{array}{ll}-0.145 & 0.528\end{array}$

$\begin{array}{rrrrrrr}-0.658 & * * * & -0.645 & * * * & -0.646 & * * * & \\ -0.161 & & -0.146 & & -0.148 & & 0.618 \\ 0.985 & * * * & 0.994 & * * * & 0.994 & * * * & \\ 1.268 & * * * & 1.283 & * * * & 1.279 & * * * & \\ -0.120 & * * * & -0.120 & * * * & -0.122 & * * * & -0.155 \\ 0.001 & * * * & 0.001 & * * * & 0.001 & * * * & 0.001 \\ 0.301 & & 0.336 & * & 0.325 & & 0.786\end{array}$

$\begin{array}{rrrrrrr}0.385 & * & 0.371 & * & 0.359 & * & -0.323 \\ -0.703 & * * * & -0.724 & * * * & -0.732 & * * * & -1.009 \\ 0.150 & & 0.154 & & 0.141 & & -0.704 \\ 0.092 & & 0.085 & & 0.088 & & -0.134\end{array}$

$\begin{array}{lllllllll}0.602 & * * * & 0.611 & * * * & 0.601 & * * * & 0.197 & \\ 1.283 & * * * & 1.287 & * * * & 1.289 & * * * & 2.740 & * * *\end{array}$

$\begin{array}{rrrrrrr}-0.394 & * * & -0.409 & * * * & -0.412 & * * * & 0.356 \\ -0.620 & * * * & -0.682 & * * * & -0.674 & * * * & -0.014 \\ -0.129 & * * * & -0.134 & * * * & -0.133 & * * * & -0.117\end{array}$

$\begin{array}{llll}-0.181 & -0.174 & -0.183 & 0.316\end{array}$

\begin{tabular}{rrrrrrrr}
-0.044 & & -0.033 & & -0.030 & & 0.109 \\
-3.128 & $* * *$ & -3.252 & $* * *$ & -3.161 & $* * *$ & -6.865 & $*$ \\
\hline
\end{tabular}


Table 3 continued

\begin{tabular}{|c|c|c|c|c|c|c|c|c|}
\hline & \multicolumn{2}{|l|}{ Model 5} & \multicolumn{2}{|l|}{ Model 6} & \multicolumn{2}{|l|}{ Model 7} & \multicolumn{2}{|c|}{ Model 8} \\
\hline & \multicolumn{2}{|c|}{ Everyone } & \multicolumn{2}{|c|}{$\begin{array}{l}\text { Everyone less } \\
\text { pre-1989 } \\
\text { RTB-owners }\end{array}$} & \multicolumn{2}{|c|}{$\begin{array}{l}\text { Everyone less } \\
\text { pre } 1991 \\
\text { RTB-owners }\end{array}$} & \multicolumn{2}{|c|}{$\begin{array}{l}\text { Social renters } \\
\text { and RTB- } \\
\text { owners }\end{array}$} \\
\hline & \multicolumn{2}{|c|}{$\mathrm{n}=64,199$} & \multicolumn{2}{|c|}{$\mathrm{n}=62,023$} & \multicolumn{2}{|c|}{$\mathrm{n}=61,229$} & \multicolumn{2}{|c|}{$\mathrm{n}=14,512$} \\
\hline & \multicolumn{2}{|c|}{$\mathrm{HHs}=10,221$} & \multicolumn{2}{|c|}{$\mathrm{HHs}=9,990$} & \multicolumn{2}{|c|}{$\mathrm{HHs}=9,899$} & \multicolumn{2}{|c|}{$\mathrm{HHs}=2,896$} \\
\hline & Coef. & Sig. & Coef. & Sig. & Coef. & Sig. & Coef. & Sig. \\
\hline \multicolumn{9}{|l|}{ Random part } \\
\hline variance & 1.56 & & 1.53 & & 1.54 & & 5.43 & \\
\hline Intraclass correlation & $32.1 \%$ & & $31.7 \%$ & & $31.9 \%$ & & $62.3 \%$ & \\
\hline Log likelihood & -2656.06 & & 2613.62 & & 2583.14 & & -307.882 & \\
\hline
\end{tabular}

Source Author's calculations using data from the BHPS

$* p<0.10$; ** $p<0.05$; *** $p<0.01$

differences in mobility. First, we included interaction terms between region dummies (10 regions based on government office regions) and tenure dummies in the models. Second, we added regional characteristics to the household-year file using special licence Local Authority District (LAD) data. We hypothesised that in regions with high house prices, RTB-owners would be more likely to move over longer distances (to other regions where houses were relatively cheaper). We also hypothesised that in regions with high levels of unemployment RTB-owners would be more likely to move over longer distances (to regions with better employment prospects). The models including interaction effects between region and tenure did not change the effects of tenure on short and long distance moves. Most of the region dummies were not significant and we found no specific effects for RTB-owners. Londoners were significantly less likely to move short distances than people resident in the reference category of 'rest of South East'. Those from Wales, Scotland and Northern Ireland were the least likely to move over short distances. The least likely to move over long distances were those from the West Midlands, the North West and Tyne and Wear and the rest of the North East. To model the effects of regional characteristics on mobility behaviour we used multilevel models. House prices and unemployment levels had almost no effect on the tenure parameters. As expected, the higher house prices were in a region, the more likely people were to move out over a long distance (small effect). We found no specific effects for RTB-owners. To investigate whether RTB-

Table 4 Percentages of moves for employment reasons by tenure type at $\mathrm{t}-1$ (row percentages)

Source Author's calculations using data from the BHPS

Pearson $\chi^{2}$ : value $=93.554$, $d f=4, p=0.000$

\begin{tabular}{lccr}
\hline Tenure type & Yes $(\%)$ & No $(\%)$ & Count \\
\hline Traditional owner & 10.01 & 89.99 & 1,948 \\
Social renting & 4.75 & 95.25 & 821 \\
Private renting & 12.25 & 87.75 & 751 \\
RTB-owner & 7.45 & 92.55 & 94 \\
Renting 'other' & 35.23 & 64.77 & 88 \\
Total & 9.83 & 90.17 & 3,702 \\
\hline
\end{tabular}


owners behaved different over time, we included period (year) dummies in the model and interacted these with tenure dummies (results not shown). Possibly due to small numbers we did not find any significant and systematic effect of period on moving behaviour.

Finally, we explored moving reasons by tenure to get more insight in the moving behaviour of RTB-owners. Table 4 shows that among movers, other renters were the most likely to move for employment reasons $(35.2 \%)$, followed by private renters $(12.3 \%)$, traditional owners $(10.0 \%)$, RTB-owners $(7.5 \%)$ and social renters $(4.8 \%)$. RTB-owners once again fell between traditional owners and social renters. A $\chi^{2}$ test showed that the differences between the tenure groups are significant $(p=0.000)$. Table 5 gives an overview of moving reasons based on another BHPS question with more categories. We recoded the original 35 moving reasons in the BHPS into fewer categories using the criteria of Boheim and Taylor (2002). Overall, 'housing related issues' were the most important reason for moving (almost $40 \%$ of moves) for all tenures, followed by 'neighbourhood related issues' $(13.7 \%)$. RTB-owners were more likely to move for neighbourhood related reasons $(23.3 \%)$ than those in any other tenure, including social renters $(18.7 \%)$. This is surprising, as we know that the uptake of the RTB was more common among those living in better properties in more popular neighbourhoods. RTB-owners also gave health related reasons as an important reason for moves $(12.8 \%)$, second only to social renters $(16.4 \%)$. This could reflect the health status of those in social housing and/or the fact that RTBowners were relatively old compared to those in other tenures. RTB-owners were the least likely to move for housing-related issues $(30.2 \%)$, probably reflecting that most of them bought their dwelling while they were reasonably satisfied with it.

\section{Conclusion}

This is the first study to use complex longitudinal data to examine whether the moving behaviour of RTB-owners is different from those living in other tenures. We used the BHPS in an innovative way to identify those who became RTB-owners during the panel. The number of RTB-owners found in the data was small, thereby pushing the limits of what can be done with the data. The small numbers of RTB-owners, and consequently the small number of long distance movers, might have influenced the parameter of the RTB-owner variable, which was never significantly different from the parameter for the traditional owners. However, the standard errors are still relatively small and the results found are in line with what could be expected. As a consequence of the small numbers, the results of this study must be interpreted with some caution. At the same time, a careful review of alternative datasets has shown that the BHPS was the best data available for this study as it uniquely allowed us to follow RTB-owners over time. So despite the shortcomings of the data for this study, there is no other dataset available which would allow us to do the same analyses.

Our results demonstrated that RTB-owners were about as likely to move over short distances as were traditional homeowners, but less likely than social renters. So after buying their house, RTB-owners showed more resemblance with the group they joined (homeowners) than the group they had departed (social renters). There are two opposing explanations for this finding: either RTB-owners are relatively satisfied with their dwelling, so there is no need for moving, or they are even more 'trapped' in their dwelling than they were before they bought it, because now they face the same moving restrictions as traditional homeowners. Homeowners are known to be less mobile than (social) renters over short distances because they live in better dwellings and because the costs associated with moving are much higher for owners than for renters. 


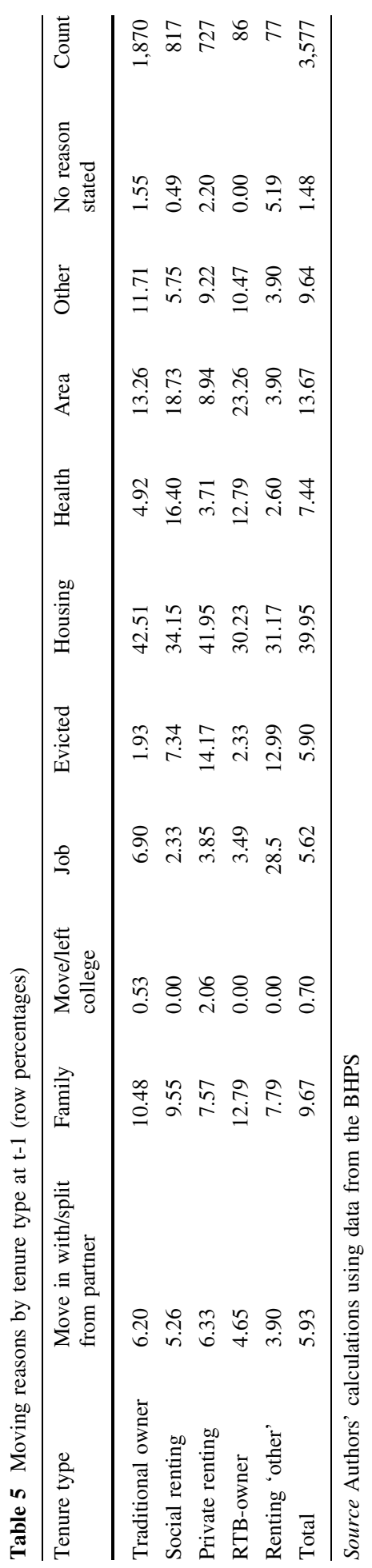


Our results suggest that RTB-owners are slightly more likely to move over long distances than social renters, and slightly less likely than traditional homeowners, although the differences were not significant. So these results need to be interpreted with caution. We have also shown that the uptake of the RTB was very selective, with mainly employed tenants with relatively high incomes and no health problems using the RTB. This suggests that RTB-owners have certain measured and unmeasured characteristics which would have made them more likely to move over long distance anyway. The combination of possible selection bias, and the lack of statistically significant differences, lead us to conclude that it is questionable whether the RTB had a causal effect on the long distance mobility behaviour of RTB-owners.

Despite large differences between regional housing markets in the UK, our study did not find any regional differences in the moving behaviour of RTB-owners. We also found no temporal effect on the moving behaviour of RTB-owners. A possible cause is the relatively low number of RTB-owners and moves by RTB-owners in our dataset.

Finally, our analyses of moving reasons showed that RTB-owners are less likely than traditional owners to move for job related reasons, but they are more likely to move for job related reasons than social renters. Again, they take a middle position between traditional owners and social renters. RTB-owners were found to be more likely to move for neighbourhood related reasons than those in any other tenure, including social renters. This is surprising since previous research has shown that RTB purchases tended to involve the best properties in the most favoured neighbourhoods. It might be the case that RTB-owners want to move to nicer neighbourhoods, possibly neighbourhoods with a higher share of owner-occupied dwellings, in order to confirm their new status as homeowners (compare Michelson 1977). To gain more insight into the role of the neighbourhood in the moving behaviour of RTB-owners, future research should look in more detail at housing satisfaction, moving desires and housing ambitions of RTB-owners.

Acknowledgments We gratefully acknowledge financial support from the Economic and Social Research Council (ESRC) (RES-000-22-2460). We would also like to thank the anonymous referees who have commented on the original research proposal and on the end-of-award report for the ESRC. Maarten van Ham and Peteke Feijten also worked on this paper while working at the University of St. Andrews.

Open Access This article is distributed under the terms of the Creative Commons Attribution License which permits any use, distribution, and reproduction in any medium, provided the original author(s) and the source are credited.

\section{References}

Black, J., \& Stafford, D. (1988). Housing policy and finance. London: Routledge.

Blau, P. M., \& Duncan, O. D. (1967). The american occupational structure. New York: Wiley.

Boheim, R., \& Taylor, M. P. (2002). Tied down or room to move? investigating the relation-ships between housing tenure, employment status and residential mobility in britain. Scottish Journal of Political Economy, 49(4), 369-392.

Boyle, P. (1993). Modelling the relationship between tenure and migration in England and Wales. Transactions the Institute of British Geographers, 18(3), 359-376.

Boyle, P. J. (1995). Public housing as a barrier to long distance migration. International Journal of Population Geography, 1, 147-164.

Boyle, P. J. (1997). Right to buy, or left to rent? Public housing in Britain. In L.-E. Borgegård, A. M. Findlay, \& E. Sondell (Eds.), Population planning and policies. Umeå: CERUM.

Buck, N. (2000). Using panel surveys to study migration and residential mobility. In D. Rose (Ed.), Researching social and economic change the uses of household panel studies (pp. 250-272). London: Routledge. 
Burrows, R. (1999). Residential mobility and residualisation in social housing in England. Journal of Social Policy, 28(1), 27-52.

Chaney, P., \& Sherwood, K. (2000). The resale of right to buy dwellings: A case study of migration and social change in rural England. Journal of Rural Studies, 16(1), 79-94.

Coleman, D., \& Salt, J. (1992). The British population: Patterns, trends and processes. Oxford: Oxford University Press.

Coulter, R., van Ham, M., \& Feijten, P. (2012). Partner (dis)agreement on moving desires and the subsequent moving behaviour of couples. Population, Space and Place, 18(1), 16-30.

Dieleman, F. M. (2001). Modelling residential mobility; A review of recent trends in research. Journal of Housing and the Built Environment, 16, 249-265.

Dietz, R. D., \& Haurin, D. R. (2003). The social and private micro-level consequences of homeownership. Journal of Urban Economics, 54(3), 401-450.

Forrest, R. (1987). Spatial mobility, tenure mobility and emerging social divisions in the UK housing market. Environment and Planning A, 19, 1611-1630.

Forrest, R., Gordon, D., \& Murie, A. (1996). The position of former council homes in the housing market. Urban Studies, 33(1), 125-136.

Forrest, R. \& Murie, A. (1984a). Right to Buy? Issues of Need, Equity and Polarisation in the Sale of Council Houses. Working Paper No. 39, School for Advanced Urban Studies, University of Bristol.

Forrest, R., \& Murie, A. (1984b). Monitoring the right to buy. SAUS: University of Bristol.

Forrest, R., \& Murie, A. (1988). Selling the welfare state. London: Routledge.

Forrest, R., \& Murie, A. (1990). Residualisation and council housing: A statistical update. Bristol: SAUS, University of Bristol.

Forrest, R., \& Murie, A. (1992). Housing as a barrier to the geographical mobility of labour. In A. G. Champion \& A. J. Fielding (Eds.), Migration processes and patterns, Vol. 1: Research progress and prospects (pp. 55-64). London: Belhaven Press.

Forrest, R., Murie, A., \& Gordon, D. (1995). The resale of former council dwellings in England. London: HMSO.

Foulis, M. (1985). Council house sales in Scotland. Scottish Office: Edinburgh.

Hamnett, C. (1992). House-price differentials, housing wealth and migration. In A. G. Champion \& A. J. Fielding (Eds.), Migration processes and patterns, Vol. 1: Research progress and prospects (pp. 55-64). London: Belhaven Press.

Hansard, H. C. (1980). Housing Bill, second reading. House of Commons.

Helderman, A., Mulder, C. H., \& van Ham, M. (2004). The changing effect of home ownership on residential mobility in the Netherlands, 1980-98. Housing Studies, 19(4), 601-616.

Helderman, A. C., van Ham, M., \& Mulder, C. H. (2006). Migration and home ownership. Tijdschrift voor Economische en Sociale Geografie, 97(2), 111-125.

Hughes, G., \& McCormick, B. (1981). Do council housing policies reduce migration between regions? The Economic Journal, 91(364), 919-937.

Hughes, G. A., \& McCormick, B. (1985). Migration intentions in the U.K. Which households want to migrate and which succeed? The Economic Journal, 95, 113-123.

Hughes, G., \& McCormick, B. (1987). Housing markets, unemployment and labour market flexibility in the UK. European Economic Review, 31(3), 615-641.

James, S., Bill, J., \& Kay, H. (1991). Poor people, council housing and the right to buy. Journal of Social Policy, 20(1), 27-40.

Jones, C., \& Murie, A. (1998). Reviewing the right to buy. Birmingham: School of Public Policy, University of Birmingham.

Jones, C., \& Murie, A. (2006). The right to buy. Analysis \& Evaluation of a Housing Policy. Blackwell, Oxford.

Kerr, M. (1988). The right to buy: A national survey of tenants and buyers of former council houses. London: HMSO.

Lynn, P. (1991). The Right to Buy: A national follow-up survey of tenants of council homes in England. London: HSMO.

Michelson, W. (1977). Environmental choice, human behavior, and residential satisfaction. New York: Oxford University Press.

Mulder, C. H., \& van Ham, M. (2005). Migration histories and occupational achievement. Population Space Place, 11(3), 173-186.

Nickell, S. (1998). Unemployment: questions and some answers. Economic Journal, 108, 802-816.

Oswald, A. J. (1999). The housing market and Europe's unemployment: A non-technical paper. Coventry: University of Warwick. 
Pawson, H., \& Bramley, G. (2000). Understanding recent trends in residential mobility in council housing in England. Urban Studies, 37, 1231-1259.

Pawson, H., \& Watkins, C. (1998a). The position and role of former public sector homes in the owneroccupied sector: New evidence from the Scottish housing market. Urban Studies, 35(8), 1291.

Pawson, H., \& Watkins, C. (1998b). The resale of former public sector homes in rural Scotland. The Scottish Geographical Magazine, 114(3), 157-163.

Rossi, P. H. (1955) Why families move. A study in the social psychology of urban residential mobility. (Glencoe, Illinois, Free Press).

Saunders, M. N. K. (1985). The influence of job-vacancy advertising upon migration: Some empirical evidence. Environment and Planning A, 17(12), 1581-1589.

Sjaastad, L. A. (1962). The costs and returns of human migration. Journal of Political Economy, 70, 80-93.

Thatcher, M. (1980). Speech to Welsh Conservative Party Conference ("Contract with Realism”), July 1980 at the Patti Pavilion, Swansea. Thatcher Archive: speaking text.

van Ham, M. (2002). Job access, workplace mobility, and occupational achievement. Eburon: Delft.

van Ham, M. (2012). Housing behaviour. In D. Clapham, W. A. V. Clark, \& K. Gibb (Eds.), Handbook of housing studies, Chapter 3. London: Sage.

van Ham, M., \& Clark, W. A. V. (2009). Neighbourhood mobility in context: household moves and changing neighbourhoods in the Netherlands. Environment and Planning A, 41, 1442-1459.

van Ham, M., \& Feijten, P. M. (2008). Who wants to leave the neighbourhood? The effect of being different from the neighbourhood population on wishes to move. Environment and Planning A, 40, 1151-1170.

van Ommeren, J., Rietveld, P., \& Nijkamp, P. (2000). Job mobility, residential mobility and commuting: A theoretical analysis using search theory. The Annals of Regional Science, 34, 213-232.

Williams, N. J., \& Sewel, J. B. (1987). Council house sales in the rural environment. In B. D. McGregor, D. S. Robertson, \& A. Shucksmith (Eds.), Rural housing in Scotland: Recent research and policy. Aberdeen: Aberdeen University Press.

Williams, N. J., \& Twine, F. E. (1994). Locals, incomers and second homes-The role of resold public sector dwellings in rural Scotland. Scandinavian Housing and Planning Research, 11(4), 193-209. 